\title{
Monika Więch (D) \\ Warsaw \\ WERE THESE JUGS AND COLANDERS \\ MADE OF COOKING WARE FABRIC \\ INTENDED FOR COOKING? \\ FINDS FROM THE POLISH EXCAVATIONS \\ OF WARSAW UNIVERSITY \\ AT NEA PAPHOS
}

\begin{abstract}
The aim of the paper is to extend the standard set of ceramic vessels used for thermal processing of food with two forms: jugs and colanders. The paper presents the functional analysis of ceramic jugs and colanders made of cooking ware found in early Roman layers of the residential quarter of ancient Nea Paphos, excavated by the Polish Archaeological Mission of Warsaw University at Kato Paphos. The examination is based on the shape of the vessels, the fabric, as well as on specific traces of use visible on the pots, such as mineral deposit on the inside or soot on the outside surface.

Keywords: Nea Paphos; early Roman period; cooking ware pottery; jugs; colanders; thermal processing of food; traces of use
\end{abstract}

\section{Introduction}

The aim of the presented paper is to extend the standard set of cooking ware pottery with an additional two forms, namely jugs and colanders (pots pierced with small holes). ${ }^{12}$ Commonly in the repertoire of cooking ware

\footnotetext{
1 I wish to express my gratitude to Dr H. Meyza for the opportunity of study of this material and for his guidance in the course of my research.

2 The study of the presented material was financed by the Institute of Mediterranean and Oriental Cultures, Polish Academy of Sciences, decision no. 209665/E-691//2016.
} 
forms, four basic types are distinguished: deep pots, shallow casseroles, flatbased pans, and lids (Catling 1972, 55-64; Rowe 2004, 170-171). However, apart from these obvious shapes on Greco-Roman (also in late Roman period) sites of the Mediterranean basin, jugs and perforated vessels appear as well (Sackett et al. 1992a, 187; 1992b, Pls 130.45, 193.59). Usually the ware of these vessels is described as kitchen or coarse, but in many publications following these statements no functional analysis ensues (Hayes 1991, 80; Sackett et al. 1992a). The author intends to examine these very vessels and to investigate in more specific ways their functions in Roman kitchens.

\section{The context of the vessels}

During Polish excavations of the University of Warsaw at Nea Paphos site (Pl. 1: 1, 2), quite a few examples of jugs and colanders of red-brown non-micaceous cooking fabrics of the Paphos region (Hayes 1991, 81) were found. No jug with a complete profile has appeared so far, and in the case of colanders almost nothing but perforated pieces of the body have been recorded. Fragments presented in the paper came from the early Roman contexts of the so-called Hellenistic House, from different rooms and courtyards (no real kitchen has been identified in the excavation area) (Więch 2017b), and the House of Aion (Pl. 2). Fieldwork seasons 2014 and 2016 were especially abundant with numerous pieces of cooking ware jugs. The explored area of the main courtyard (1) of the 'Hellenistic' House has yielded mostly early Roman (1st - early 2nd century AD) layers, rather homogeneous in terms of pottery (Meyza H. et al. 2017, 399-401). Some of the presented pots come from well S.16.3 in the House of Aion, also dated to the early Roman period, or from small trial pits (usually $1 \mathrm{~m} \times 1 \mathrm{~m}$ ), which were dug out during salvage excavations in 2007 and 2008, due to the planned roof construction to protect the site. Among several documented examples only a few of them - one found in 1981 in the Hellenistic House and another two in 2008 in the House of Aion in well S.16.3 - come from deposits. Still, the beginning of the presence of the discussed cooking jugs can be dated with a high degree of certainty to the end of the 1st century $\mathrm{BC} /$ beginning of the 1 st century $\mathrm{AD}$, due to the contexts from which they originate as well as typological analogies. In the case of colanders, because of their rare occurrence and very fragmentary preservation, the dating is based almost only on contexts, although it seems that it is possible to distinguish Hellenistic colanders from early Roman ones based on surface treatment, as well as the size, arrangement and finishing of the vessel perforations. 


\section{Why cooking vessels?}

Pots are defined as used for cooking on the basis of their shape, fabric and surface treatment and specific traces of use, for example soot marks (Ben-Shlomo et al. 2008). In the given group of jugs and colanders only exceptionally are all four variables met. Therefore, during the selection process the author focused especially on the fabric, which is the only constant factor in all fragments; taking the following assumption: since the cooking vessels must have certain characteristics such as thermal shock resistance and good heat conduction, if the vessel fulfills these criteria, that means it is intended for cooking (Schiffer et al. 1994, 199). Setting clear selection criteria of the material is crucial, because aside from a few jug types described in this paper - which according to the author were used for boiling water - there are as well jugs of quite another function, namely for storage and serving of liquids. The differences between those two groups are visible in fabric, shape and wall thickness.

\section{Methodology}

The vessels were selected from the contexts on the basis of macroscopic study of fabric and shape. The fabric examination was based on the classification of the ceramic assemblage into groups according to the following parameters: sorting, frequency, size, shape and color of inclusions; frequency and shape of voids; color of fresh break and surface; visual texture of fresh break; and hardness. The classification and description system adopted in this study, with modification according to the voids and inclusions, was proposed by Orton, Tyres and Vince, as presented in Pottery in archaeology (1993, 221-242). Fabrics were examined by naked eye and with a $\times 10$ magnifying glass in natural light. Then a Delta Optical Smart 2 MPix digital microscope and a Nikon SMZ1000 binocular microscope were used to support the classification into groups and for optical analysis of clay and inclusions. Combinations of names and numeric codes (in brackets) from the Munsell soil color chart $^{3}$ were used to determine the color, and an alternative for the Mohs' hardness scale test using a fingernail, window glass, and a knife to determine the hardness of the vessels (Orton et al. 1993, 69, 139, 233).

The definitions of terms used in Table 1 to describe macroscopic groups (MGs) are: inclusions sorting: very poor, poor, fair, good, very good (Orton

\footnotetext{
${ }^{3}$ Munsell Soil Color Book 2009 Year Revised, 2013 Production.
} 
et al. 1993, 239-240); frequency of inclusions / voids: rare - less than 4\%, few $-4-8 \%$, common $-8-14 \%$, frequent $-14-20 \%$; size of inclusions / voids (dominant dimension): fine $-0.1-0.25 \mathrm{~mm}$, medium $-0.25-0.5 \mathrm{~mm}$, coarse $-0.5-1 \mathrm{~mm}$; shape of inclusions: very angular, angular, subangular, subrounded, rounded, well-rounded (Orton et al. 1993, 239-240); shape of voids: rounded, elongated, irregular; texture of fresh break: smooth - flat, without ripple marks, hackly - with more inclusions, large and angular irregularities; hardness: soft - can be scratched with a fingernail, medium hard - can be scratched with window glass, hard - can be scratched with a knife. Inclusions of different colors are given from the most to the least frequent.

\section{Macroscopic fabric groups description}

The fabric of the presented jugs and colanders macroscopically does not differ from the fabric of other cooking vessels (Élaigne 2014; Gabrieli and Merryweather, 2002). Cooking ware of jugs and colanders can be divided into three macroscopic groups: macroscopic group 1 (Cypriot, presumably Paphos region cooking ware) (Hayes 1991, 81-82), macroscopic group 2 (Cypriot, presumably so-called Soli fabric) (Hayes 1991, 82) and macroscopic group 3 (Asia Minor, so-called Aegean cooking ware, possibly Phocaea region) (Hayes 2000, 292; Hayes 1991, 80).

\begin{tabular}{|c|c|c|c|}
\hline & MG $1(\mathrm{Pl} .3: 1,2)$ & MG 2 (Pl. 3: 3) & MG 3 (Pl. 3: 4) \\
\hline $\begin{array}{l}\text { Sorting, } \\
\text { frequency, } \\
\text { size, shape } \\
\text { and color } \\
\text { of inclusions } \\
\text { visible at } \\
\text { the fresh } \\
\text { break }\end{array}$ & $\begin{array}{l}\text { very poor to poor, common, } \\
\text { fine to coarse, angular to } \\
\text { rounded: } \\
\text { - white } \\
\text { - black } \\
\text { - transparent } \\
\text { - grey } \\
\text { - dark red }\end{array}$ & $\begin{array}{l}\text { good to very good, } \\
\text { frequent, fine to } \\
\text { coarse, subrounded } \\
\text { to rounded: } \\
\text { - white } \\
\text { - grey } \\
\text { - transparent } \\
\text { - black }\end{array}$ & $\begin{array}{l}\text { fair, few to } \\
\text { common, fine to } \\
\text { medium, angular to } \\
\text { subrounded: } \\
\text { - white } \\
\text { - black } \\
\text { - transparent } \\
\text { - sparkling }\end{array}$ \\
\hline $\begin{array}{l}\text { Frequency } \\
\text { and shape of } \\
\text { voids visible } \\
\text { at the fresh } \\
\text { break }\end{array}$ & $\begin{array}{l}\text { few, rounded, elongated and } \\
\text { irregular }\end{array}$ & common, elongated & $\begin{array}{l}\text { rare, rounded, } \\
\text { elongated and } \\
\text { irregular }\end{array}$ \\
\hline
\end{tabular}




\begin{tabular}{|c|c|c|c|}
\hline $\begin{array}{l}\text { Texture of } \\
\text { fresh break }\end{array}$ & smooth & hackly & smooth \\
\hline Hardness & hard & hard & medium hard \\
\hline $\begin{array}{l}\text { Color of the } \\
\text { fresh break }\end{array}$ & $\operatorname{red}(2.5$ YR $4 / 6,4 / 8,5 / 8)$ & $\begin{array}{l}\text { red }(2.5 \text { YR } 4 / 6,4 / 8, \\
5 / 8) \text {, dark reddish } \\
\text { brown }(2.5 \text { YR } 2.5 / 4)\end{array}$ & $\begin{array}{l}\text { light red } \\
(2.5 \mathrm{YR} 7 / 6,6 / 6,6 / 8)\end{array}$ \\
\hline $\begin{array}{l}\text { Color of } \\
\text { outer surface }\end{array}$ & $\begin{array}{l}\text { red }(2.5 \mathrm{YR} 4 / 8,5 / 8), \\
\text { reddish brown }(2.5 \mathrm{YR} 4 / 4), \\
\text { dark reddish brown } \\
(2.5 \mathrm{YR} 3 / 4) \text {, } \\
\text { dark reddish gray }(2.5 \mathrm{YR} 3 / 1) \text {, } \\
\text { gray }(5 \mathrm{YR} 5 / 1) \text {, dark gray } \\
(5 \mathrm{YR} 4 / 1) \text {, dark gray }(10 \mathrm{YR} \\
4 / 1)\end{array}$ & $\begin{array}{l}\text { red } \\
(2.5 \mathrm{YR} 4 / 6,4 / 8,5 / 8), \\
\text { reddish brown } \\
(2.5 \mathrm{YR} 4 / 4), \\
\text { very dusky red } \\
(2.5 \mathrm{YR} 2.5 / 2)\end{array}$ & $\begin{array}{l}\text { gray }(5 \mathrm{YR} 5 / 1) \\
\text { gray }(2.5 \mathrm{Y} 5 / 1)\end{array}$ \\
\hline Forms & $\begin{array}{l}\text { casseroles, deep pots, lids, jugs, } \\
\text { colanders }\end{array}$ & $\begin{array}{l}\text { deep pots, carinated } \\
\text { casseroles, lids, } \\
\text { colanders and related }\end{array}$ & $\begin{array}{l}\text { pots, casseroles, } \\
\text { trefoil jugs, also } \\
\text { baking dishes } \\
\text { (related macroscopic } \\
\text { group but with } \\
\text { coarse inclusions) }\end{array}$ \\
\hline $\begin{array}{l}\text { Types } \\
\text { of jugs, } \\
\text { colanders } \\
\text { and related }\end{array}$ & $\begin{array}{l}\text { jug with an external flange } \\
\text { (type I), jug with an internal } \\
\text { lid support (type II), jug } \\
\text { with L-shaped rim (type III), } \\
\text { colanders }\end{array}$ & colanders and related & trefoil jugs \\
\hline $\begin{array}{l}\text { General } \\
\text { description } \\
\text { and } \\
\text { interpretation }\end{array}$ & $\begin{array}{l}\text { Visible variations in } \\
\text { the ceramic mass, in terms } \\
\text { of the amount and size of } \\
\text { inclusions, which are likely } \\
\text { to include various form of } \\
\text { calcium carbonate, quartz, } \\
\text { dark minerals, rock particles } \\
\text { and microfossils (often } \\
\text { Foraminifera) (Quinn 2008, } \\
275-279 \text {; Orton et al. 1993, } \\
\text { 236-237; Adams et al. 1988, } \\
48-49 \text {; Rice 1987, 94-97). } \\
\text { The outer surface can be fired } \\
\text { to grey. }\end{array}$ & $\begin{array}{l}\text { Very sandy. No } \\
\text { microfossils can be } \\
\text { observed. The outer } \\
\text { surface can be fired } \\
\text { to grey. }\end{array}$ & $\begin{array}{l}\text { Characteristic are } \\
\text { mica flecks. } \\
\text { No microfossils } \\
\text { can be observed. } \\
\text { The outer surface is } \\
\text { always fired to light } \\
\text { grey. }\end{array}$ \\
\hline
\end{tabular}

Table 1. Macroscopic groups description

\footnotetext{
${ }^{4}$ Identification of inclusions was made by the author, based on observation of fresh breaks under a Nikon SMZ1000 binocular microscope, and on archaeometric literature.
} 


\section{Jugs}

\section{Paphos region}

Paphos region jugs classified to macroscopic group 1 are small (presumably about 1 liter in capacity, rim diameter: $5.5-7 \mathrm{~cm}$, base dimeter: about $5 \mathrm{~cm})$, thin-walled $(1.5-2.5 \mathrm{~mm}$ wall thickness) with narrow rim and neck (no spout or trefoil rim, which would make pouring of liquids easier) and a globular body and concave base with a central button (P1. 4: 8, 9, 11). The neck and wide shoulder are often decorated with several simple grooves. Jugs were equipped with one long solid vertical handle attached about $5 \mathrm{~mm}$ below the lip and the other end reaching the flat shoulder of the vessel, just above the largest dimension of the belly. The handle was flattened, with two or three vertical grooves along the entire length. This handle shape is characteristic not only of the discussed jugs but also of at least two types of Cypriot cooking pots of the early Roman period (Więch 2017b, Fig. 4.9). Depending on the rim form we can distinguish three types of cooking jugs.

Type I has a rim with a wide horizontal flange on the outside and was presumably produced in two sizes. So far, only two rims of this type have been registered on the site, making it much rarer than the other forms. The diameter of the rim of the larger jug is $12 \mathrm{~cm}$ (Pl. 4: 1), while of the smaller one it is $5.4 \mathrm{~cm}(\mathrm{Pl} .4: 2)$. The larger jug has been preserved to the height of the arms and it can be clearly seen that it was a much more open vessel, with a shorter neck, than jugs type II and III. This is confirmed by a complete example of this shape, found in the House of Dionysus and dated to the 2nd century AD. If lids were used to cover such jugs, they had to be exterior lids. On the larger jug there are no signs of use, on the smaller one, a white mineral deposit on the inside of the walls is visible. It is worth mentioning here that described type I was also produced in the Hellenistic period, although with a round coarse-finished bottom. ${ }^{5}$

Type II (Pl. 4: 3-7) is distinguished by its internal support for the lid and a narrow neck decorated with grooves. The diameter of the rim is usually about $5 \mathrm{~cm}$ (up to $7 \mathrm{~cm}-1$ example). No complete profile of the vessel has survived, but very similar examples, preserved from rim to shoulder heights, come from the House of Dionysus (Hayes 1991, Figs 67.19, 67.20). Apart from numerous registered rim fragments of type II, one body fragment (P1. 4: 10, Pl. 7: 3) was found in the early-Roman layer of destruction of

5 Consultation with Kamila Nocon, during a visit at the Agora Project site at Nea Paphos in 2018 . 
courtyard 1 in the Hellenistic House. The small diameter of the upper part of the neck suggests that the fragment belongs to the second or third type.

Type III (Pl. 5: 1-5) is a jug with an L-shaped rim flattened at the top, without a lid support. There are no analogies published from the House of Dionysus (Hayes 1991), which makes its classification as a cooking vessel more difficult. Rims of type III, in contrast to types I and II, are often present in table ware pottery, namely Red Slip and Plain ware jugs with thick ring bases. Despite the similarities in rim shape to the table ware jugs, type III belongs to macroscopic group 1 (as do type I and II), and often has a white deposit on the inner of the rims. As well, there were no ring bases found in the cooking fabric. These facts indicate, in the author's opinion, that type III has the same purpose as the two types described above.

The shape of the rim of types II and III was well-rooted in the local tradition of manufacturing of ceramic vessels in the Roman period. A similar rim, with an internal projection for the lid, differing only in diameter and tilt angle, can be found in deep pots and shallow casseroles (Pl. 6: 1-8), whereas type III quite faithfully reproduces the rim profile of table ware jugs (P1. 6: 9-12). On early Roman table jugs the same simple grooving occurs, highlighting the neck and shoulder of three types of cooking jugs.

\section{Imports}

In addition to the numerous fragments of jugs among the Paphos region cooking ware, at the Maloutena site small fragments of trefoil rims and hollow 'button-like' bases of jugs associated with macroscopic group 3 were recorded sporadically (P1. 5: 6-9). The fragmentary state of preservation of jugs from the Polish site allows reconstruction of only the general shape of the vessels, but more complete examples have been found on other Mediterranean sites (Knossos, Crete) (Forster 2001, 158, Fig. 4.11c).

\section{Colanders and related}

Perforated cooking vessels have been rarely found at Nea Paphos site. Only small, non-diagnostic parts of the perforated belly have been registered (P1. 8). It is possible to determine the approximate diameter and to reconstruct the supposed shape only in the case of fragments with preserved carnation on the body. Most of the early Roman colanders were rather small, not more than $15 \mathrm{~cm}$ in rim diameter.

The analysis of these interesting vessels is impeded by the small number of published analogies. A fragment of a colander - a small, shallow, perfo- 
rated bowl with carination on the belly and a preserved rim - was discovered at the Knossos site in the deposit dated to the reign of Augustus (Sackett et al. 1992a, 165, 183-184, 187; 1992b, Pl. 130.45). Another two published colanders with almost complete profiles but without preserved rims come from Nea Paphos site, from a plastered cistern found during excavations south of the Villa of Theseus in 1996 (Papuci-Władyka 1997, 135, Fig. 1.4) and from the House of Dionysus (Hayes 1991, 139, Fig. 34.100). In both cases the perforated vessels are reconstructed as shallow, open forms. This is logical for reasons of utility, although the study of the angle of carination on the body fragments recently found at the Polish excavations suggests that one of the presented colanders was a closed vessel, similar in form to a jug or lagynos (P1. 8: 3).

\section{Traces of use as an indication of the purpose}

\section{White mineral deposit on the inside}

A white deposit (P1. 7: 3), most probably lime (Hayes 1991, 84), does not exist on the inside of the perforated vessels, but it can be observed in most of the collected cooking ware jugs. The deposit usually starts approximately $1 \mathrm{~cm}$ below the rim's edge, and sometimes it is visible on the ledge to support the lid (Więch 2017a, Fig. 6). Although this kind of deposit may form while storing water (London et al. 1990, 33-34) ${ }^{6}$ it is more likely that, in the case of the jugs identified as cooking vessels, this is the result of boiling water, which gives the same effect, but faster. White deposit was observed on cooking vessels and some trefoil jugs found in Knossos (Forster 2001, 158). Globular pots and casseroles from Maloutena site do not show this kind of trace of use, most probably because wide-mouthed and carination-free vessels were easy to clean out. The rims and necks of the discussed jugs are very narrow, making proper washing impossible. The narrow rim diameter also suggests to the author that they were used only for boiling liquids.

\section{Soot}

Very rarely on the exterior surface of jugs soot can be seen, indicating their use in fire. However, it should be kept in mind that this is similar for other cooking vessels, especially of the Roman period. Most likely there are

${ }_{6}$ On Cyprus still are known so-called kouzes, 1-handled water jugs of different sizes and 2-handled stamnia, which were used for transporting water; today both forms are used as water coolers and for purification. Water is kept cool by the slow evaporation of water through the porous walls. A jug will function for one or two years before the pores become so clogged that it must be replaced or refired to remove the mineral deposits. 
two reasons for this. First, various types of stoves and braziers were in use, thanks to which the dishes did not have direct contact with fire (Ault 2015, 207-209, 211; Salque 2012, 129; Sparkes 1962, 129, Figs 5.5-5.6, 6.4-6.6; Tsakirgis 2007, 228-229). Second, the opportunity to observe the occurrence of soot was mainly influenced by the condition of the vessels - in the case of jugs, the recorded fragments are usually rims. Shallow cooking pots, such as casseroles, often show signs of soot on the rim; in the case of high jugs this is impossible. From the several registered bottoms belonging to jugs, on one example soot is visible, which indicates the use of the vessel as a cooking utensil (Pl. 7: 4). On the inside of this base fragment a thick mineral deposit is present.

Traces of soot on the perforated vessels can be observed only on small fragments of the lower part the body, not on the bottom itself. Soot, or actually burn, is most clearly visible on the sherd of the vessel whose walls were only partially perforated (Pl. 8: 5). A vessel from a plastered cistern found during excavations south of the Villa of Theseus in 1996 was also slightly blackened, just above the carination (Papuci-Władyka 1997, Fig. 1.4).

\section{Conclusions}

Considering shape, fabric and the specific traces of use, the most probable function of the discussed jugs is as vessels for boiling liquids, most probably water. Much less clear is the use of ceramic colanders. The basic function of colanders is the separation of liquid from a solid substance. During the Roman period, as we know from Apicius's De re coquinaria, colanders or strainers were present in the repertoire of kitchen utensils (Apicius 4.2.9, 4.2.33, 4.2.36, 4.4.1, 7.11.7, 8.4.3). They often served for straining and cooling of wine and other liquids using snow. Those vessels most likely were bronze hemispherical bowls with one long horizontal handle (Harcum 1921, 41).

The ceramic colanders could have had other functions, among them one connected with heating, smoking or steaming of the contents. The pierced vessels from the Polish site are made of clay used to produce pots, intended for the thermal processing of food. There are no examples of that kind of vessel (with holes made before firing) in other ceramic wares. Thus, it seems that regarding ceramic colanders we must deal with the complex function of the vessel, in which one can simultaneously (or in turn) strain (dry) the contents and/or heat them. Traces of soot on some perforated fragments 
indicate the use of colanders in contact with fire. Also, the example from the House of Dionysus is blackened in places (Hayes 1991, 139, Fig. 34). We must keep in mind as well that the holes of the studied vessels are very small (approximately $1 \mathrm{~mm}$ in diameter). According to the author, the possibly purposes are: to roast nuts (Apicius 4.2.2, 6.5.6, 6.6.10. Apicius in his cookery book often mentions roasted pine nuts, hazelnuts and almonds); to smoke the contents; or to heat milk curds during the process of cheesemaking (although the exact role of cooking ware colanders bearing marks of thermal food processing would be unclear here).

Perforated clay vessels have been found in many Mediterranean sites of the Greco-Roman period (Athenian Agora, Knossos) (Sackett et al. 1992b, Pl. 193.59), but their publications do not offer a full spectrum of analyses that would allow us to answer questions about their functions. That is why the author refers to a project carried out in Poland at a prehistoric sites from the region of Kuyavia (Salque et al. 2013). The project at Kuyavia, investigating Linear Pottery sieves using archaeometry methods, reconstructs their function as vessels for separating liquid from cheese curds, without heating. This is in line with the plain white cheese production process of today, which involves the coagulation of milk, yielding the semi-solid curds and then straining off the liquid whey. High temperature is used at the beginning of the process to speed up the coagulation of the milk and should be done in a solid vessel, not a perforated one. However, we do not know the exact cheesemaking process of the Roman period (Columella 1941, 7.8, cheese making), and traditional cheese prepared today on Cyprus includes more heating steps (Sitas 1995, 44) than does plain white cheese production in Central Europe. Perforated vessels of Greek and Roman periods excavated on Cyprus have not yet been submitted to the analysis of organic residues, which could answer the questions of cheese processing in these pots. 


\section{References}

Adams A. E., MacKenzie W. S., Guilford C. 1988. Atlas of Sedimentary Rocks under the Microscope. London.

Apicius 2012. O sztuce kulinarnej: ksiag dziesięć, trans. I. Mikołajczyk and S. Wyszomirski. Torun.

Ault B. A. 2015. Kitchens. In J. Wilkins and R. Nadeau (eds), A Companion to Food in the Ancient World, 206-211. Oxford. https:// doi.org/10.1002/9781118878255.ch19.

Ben-Shlomo D., Shai I., Zukerman A., Maeir A. M. 2008. Cooking Identities: Aegean-style Cooking Jugs and Cultural Interaction in Iron Age Philistia and Neighboring Regions. AJA 112, 225-246. https://doi. org/10.3764/aja.112.2.225.

Catling H. W. 1972. An Early Byzantine Pottery Factory at Dhiorios in Cyprus. Levant 4, 1-82. https://doi.org/10.1179/lev.1972.4.1.1.

Columella L. J. M. 1941. On Agriculture: With a Recension of the Text and an English Translation, trans. E. S. Forster and E. Heffner. London, Cambridge. https://doi.org/10.5962/bhl.title.33440.

Élaigne S. 2014. Les céramiques à paroi fine dans l'Orient du début de l'empire et leurs imitations égyptiennes, cnidiennes et paphiennes. RCRFActa 43, 19-26.

Forster G. 2001. The Roman period. In J. N. Coldstream, L. J Eiring and G. Forster, Knossos pottery handbook: Greek and Roman, 137-167 (BSA Studies7). London.

Gabrieli R. S., Merryweather A. D. 2002. A Preliminary Study of Hellenistic and Roman Kitchen Ware from Nea Paphos. In F. Blondé, P. Ballet and J.-F. Salles (eds), Céramiques hellénistiques et romaines: Productions et diffusion en Méditerranée Orientale (Chypre, Egypte et Côte Syro-Palestinienne). Actes du colloque tenu à la Maison de 1'Orient-Méditerranéen-Jean Pouilloux, 2-4 mars 2000, 33-41. (Travaux de la Maison de l'Orient Méditerranéen 35). Lyon.

Harcum C. G. 1921. Roman Cooking Utensils in the Royal Ontario Museum of Archaeology. AJA 25, 37-54. https://doi.org/10.2307/497888.

Hayes J. W., 2000. From Rome to Beirut and beyond: Asia Minor and Eastern Mediterranean Trade Connections. RCRFActa 36, 285-297.

Hayes J. W. 1991. Paphos 3. The Hellenistic and Roman pottery. Nicosia.

London G., Egoumenidou F. and Karageorghis V. 1990. Töpferei auf Zypern, damals - heute / Traditional Pottery in Cyprus. Zabern, Mainz am Rhein. 
Meyza H., Romaniuk M., Więch M. and Mazanek-Somerlik D. 2017. Nea Paphos. Seasons 2014 and 2016, Appendix 1: Note on the Pottery from Circular Basin S.1/16, Appendix 2: Glass. PAM 26/1, 399-428. https://doi.org/10.5604/01.3001.0012.1797.

Orton C. R., Tyers P. A., Vince A. G., 1993. Pottery in Archaeology, Cambridge Manuals in Archaeology. Cambridge; New York, NY.

Papuci-Wladyka E. 1997. Nea Paphos. The Cistern South of the Villa of Theseus. PAM 9, 130-135.

Quinn P. S. 2008. The Occurrence and Research Potential of Microfossils in Inorganic Archaeological Materials. Geoarchaeology 23, 275-291. https://doi.org/10.1002/gea.20213.

Rice P. M. 1987. Pottery Analysis: A Sourcebook. Chicago.

Rowe A. H. 2004. Reconsidering Late Roman Cyprus: Using New Material from Nea Paphos to Review Current Artefact Typologies. (Ph.D. Thesis, University of Sydney). Sydney.

Sackett L. H., Branigan K., Callaghan P. J., Catling H. W., Catling, E. A., Coldstream, J. N., Higgins R. A., Popham M. R., Price J., Price M. J. and Waywell G. B. 1992a. Knossos: from Greek city to Roman colony. Excavations at the Unexplored Mansion II. Part 1: Text. (BSA Suppl. 21). Oxford.

Sackett L. H., Branigan K., Callaghan P. J., Catling H. W., Catling E. A., Coldstream J. N., Higgins R. A., Popham M. R., Price J., Price M. J., Smith D. and Waywell G. B. 1992b. Knossos: from Greek city to Roman colony. Excavations at the Unexplored Mansion II. Part 2: Plates. (BSA Suppl. 21). Oxford.

Salque M., Bogucki P. I., Pyzel J., Sobkowiak-Tabaka I., Grygiel R., Szmyt M. and Evershed R. P. 2013. Earliest Evidence for Cheese Making in the Sixth Millennium BC in Northern Europe. Nature 493, 522-525. https://doi.org/10.1038/nature11698.

Salque M. 2012. Was Milk Processed in These Ceramic Pots? Organic Residue Analyses of European Prehistoric Cooking Vessels. In F. Feulner (ed.), May Contain Traces of Milk: Investigating the Role of Dairy Farming and Milk Consumption in the European Neolithic,127-141. York.

Schiffer M. B., Skibo, J. M., Boelke T. C., Neupert M. A. and Aronson M. 1994. New Perspectives on Experimental Archaeology: Surface Treatments and Thermal Response of the Clay Cooking pot. AmerAnt 59, 197-217. https://doi.org/10.2307/281927. 
Sitas A. 1995. Kopiaste: The Cookbook of Traditional Cyprus Food. Special Sections on Customs and Tradition. Limassol.

Sparkes B. A. 1962. The Greek Kitchen. JHS 82, 121-137. https://doi. org/10.2307/628548.

Tsakirgis B. 2007. Fire and Smoke: Hearths, Braziers and Chimneys in the Greek House. In R. Westgate, N. Fisher and J. Whitley (eds), Building Communities: House, Settlement and Society in the Aegean and Beyond. Proceedings of a conference held at Cardiff University, 17-21 April 2001, 225-231. (BSA Studies 15). Athens.

Więch M. 2017a. Cooking Ware Pottery from the "Hellenistic" House at Nea Paphos. Seasons 2014 and 2016. PAM 26/1, 441-452. https://doi. org/10.5604/01.3001.0012.1799.

Więch M. 2017b. Searching for the Kitchen in the Early Roman Phase of the 'Hellenistic' House at Nea Paphos (Cyprus). ÉtTrav 30, 439-457. https://doi.org/10.12775/EtudTrav.30.021.

Monika Więch Institute of Mediterranean and Oriental Cultures PAS mwiech@iksio.pan 


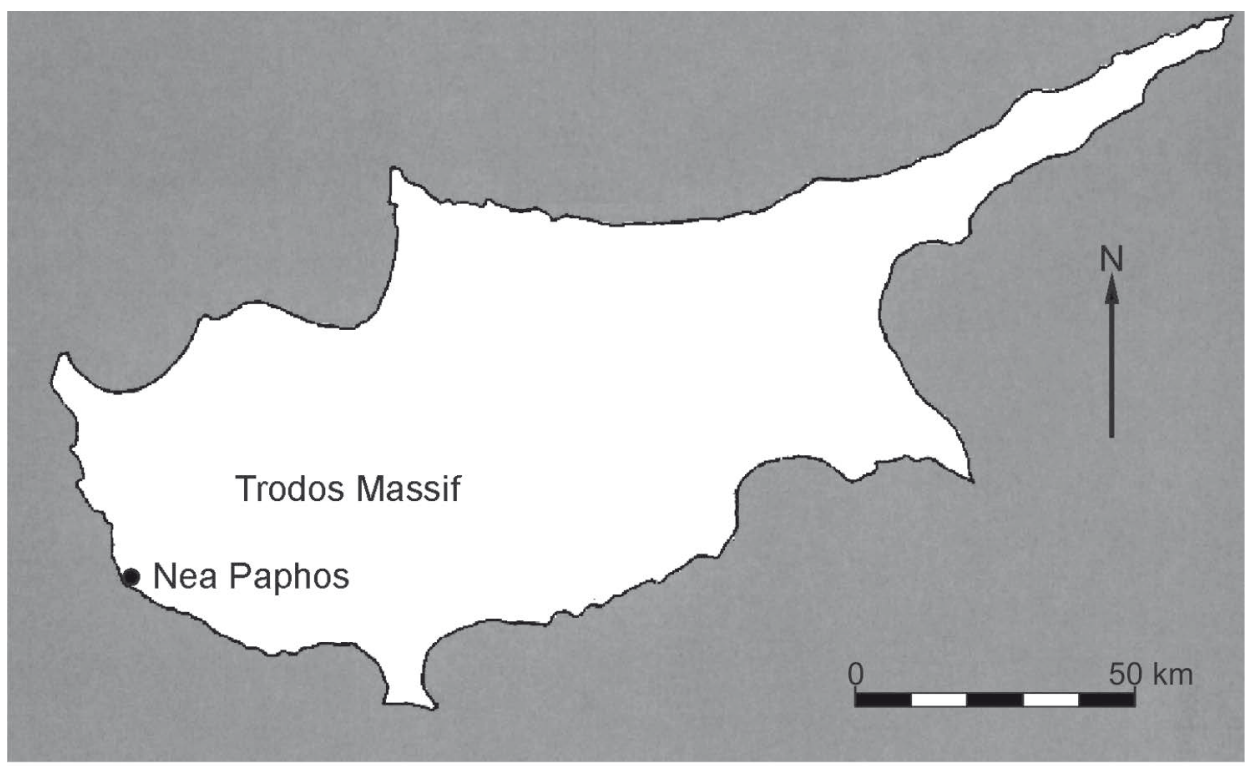

1

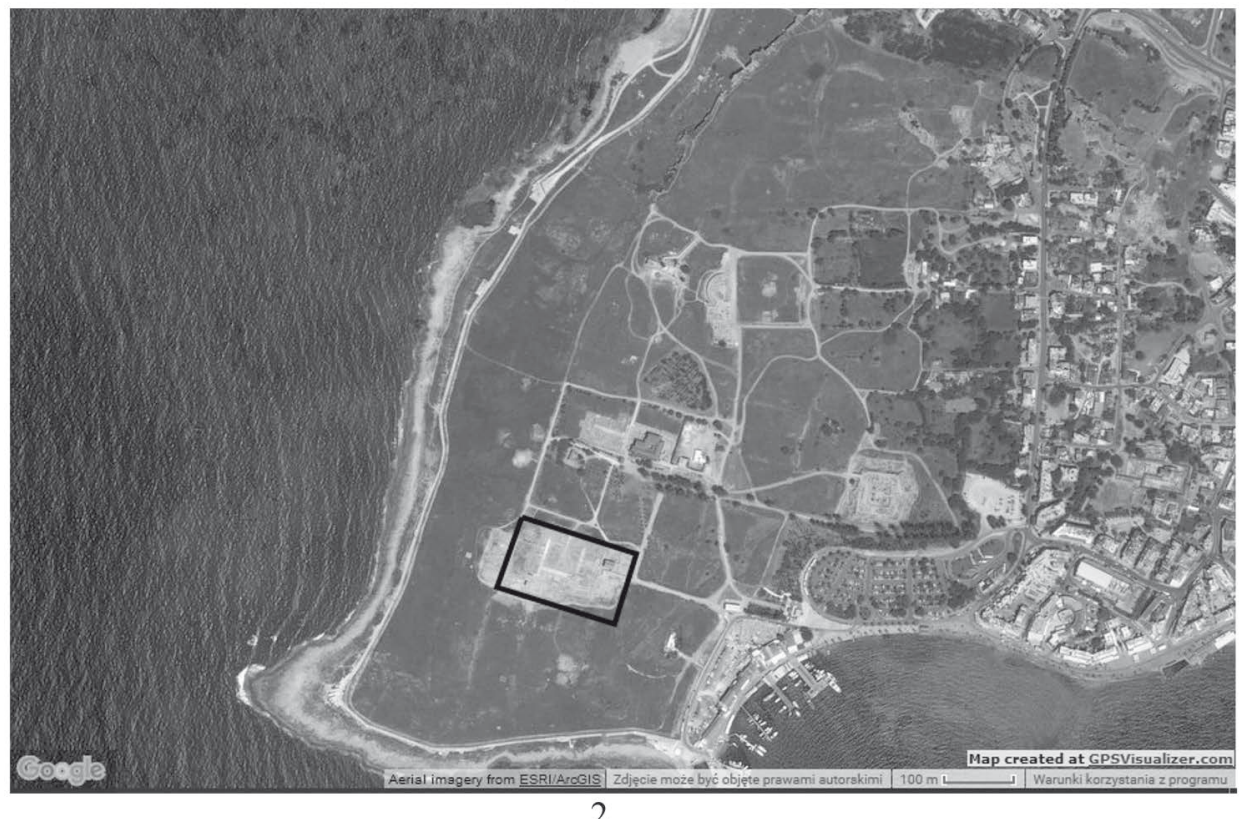

P1. 1.: 1 - Map of Cyprus with the location of Nea Paphos; 2 - Satellite imagery of the site with the area of excavation marked 


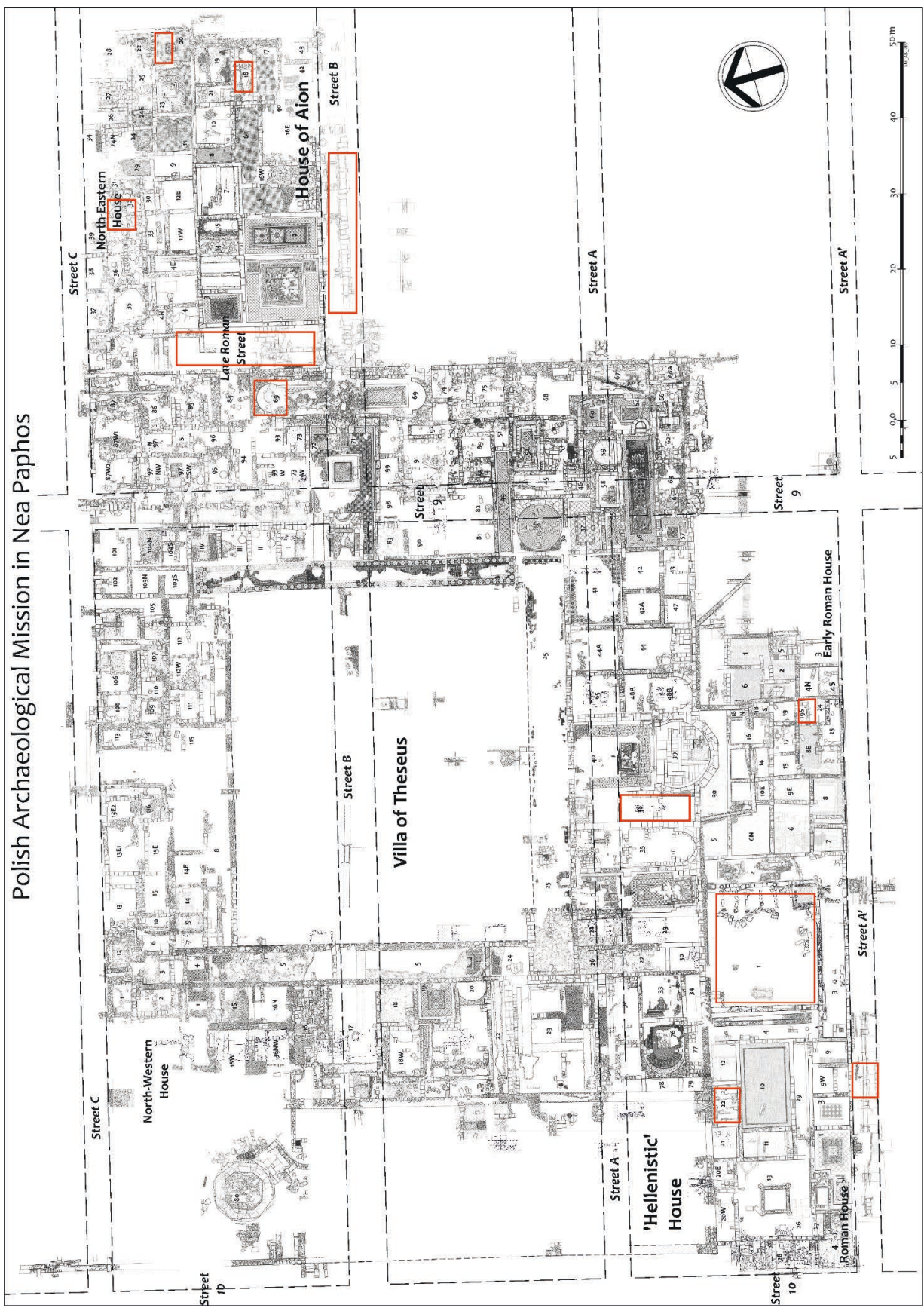

P1. 2 - Plan of the area excavated at Nea Paphos by the Polish Archaeological Mission of Warsaw University (drawing: S. Medeksza, A. Brzozowska-Jawornicka, M. Słowińska with modifications by the author) 


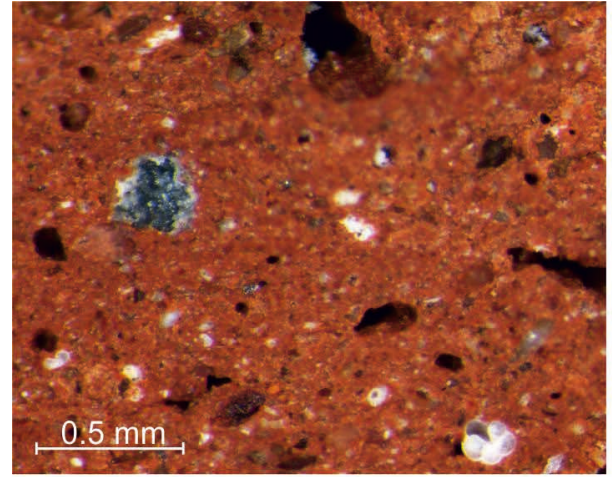

1

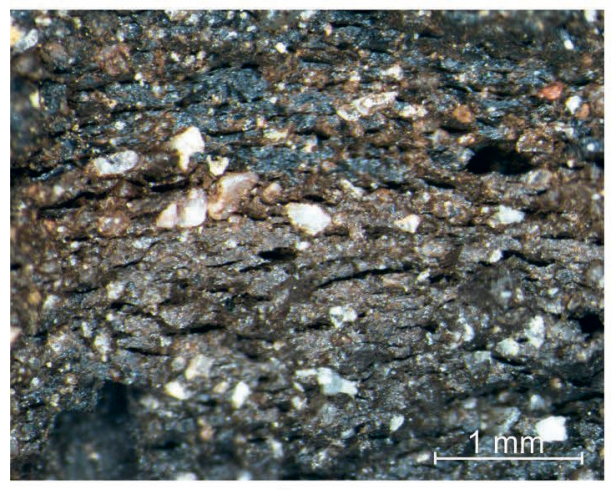

3

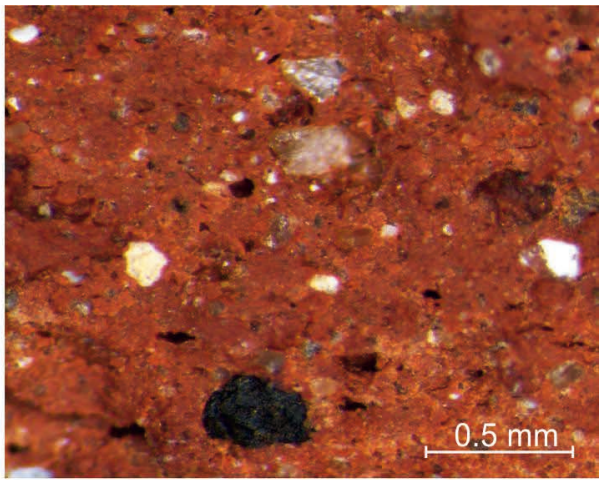

2

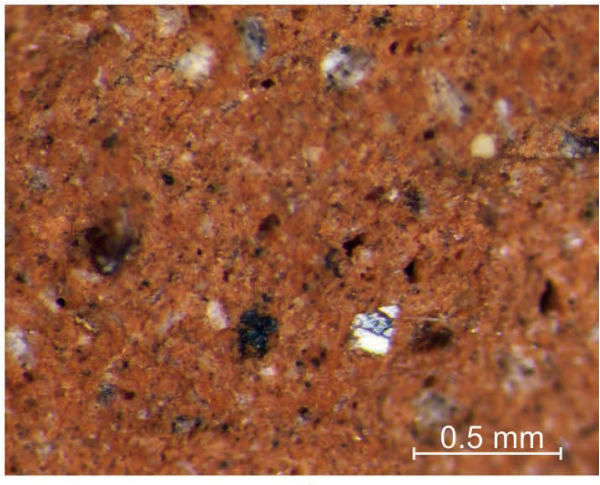

4

P1. 3 - Pictures of fresh breaks of the described macroscopic groups: 1, 2 - MG 1, jugs; 3 - MG 2, colander related vessel with partially pierced walls; 4-MG 3, trefoil jug (photos taken by the author with Nikon SMZ1000 binocular microscope, Nikon DS-Fi2 camera, photos 1, 2, 4- magnification 4x, 3 - magnification $2 \mathrm{x}$ ) 

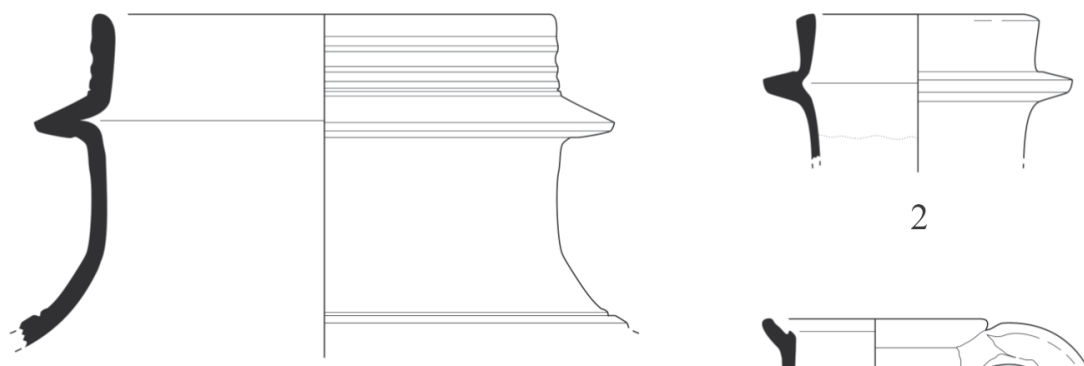

2

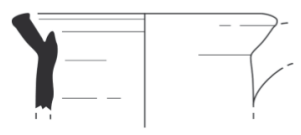

3
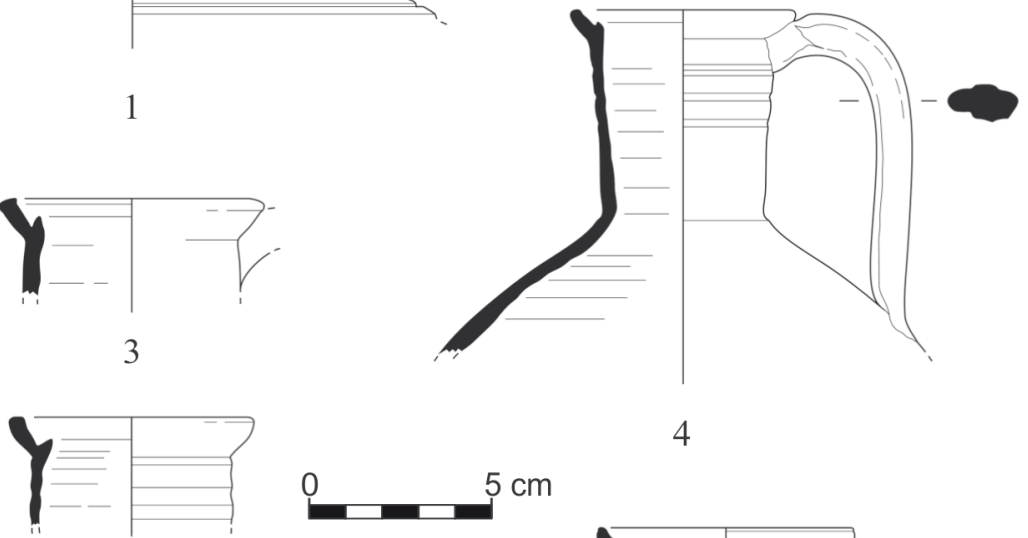

4

5
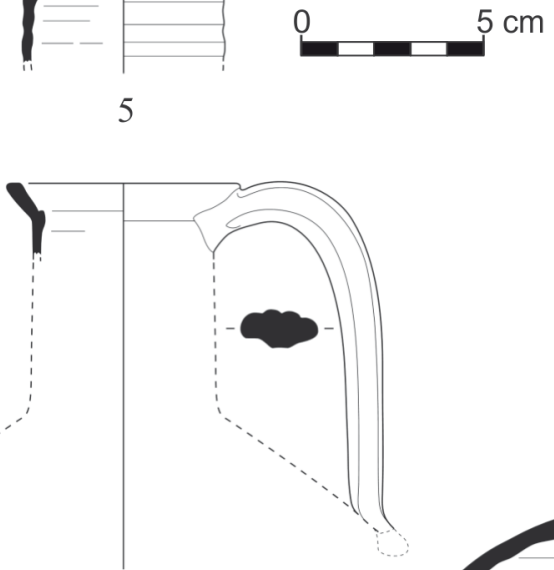

6
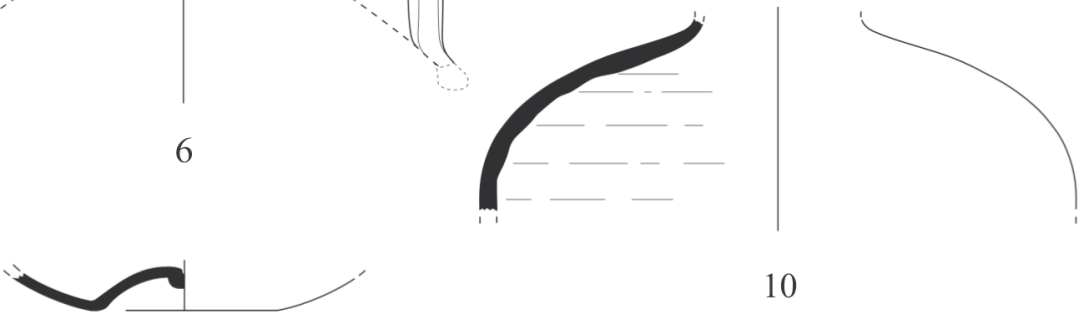

10

8

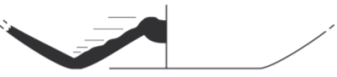

9

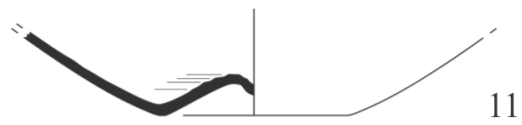

Pl. 4 - Cypriot cooking ware jugs from Maloutena site: 1-2 - type I; 3-7, 10 - type II; $8,9,11$ - types I, II or III: Drawing and digitalization by the author 

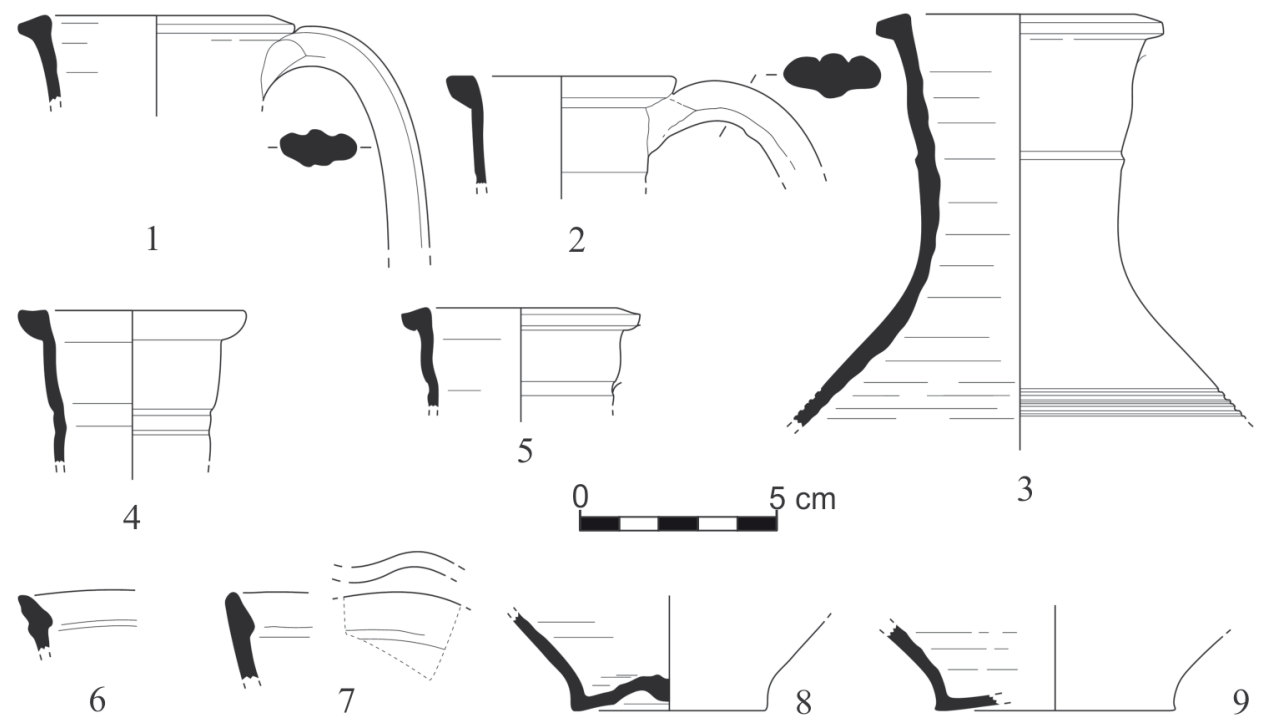

P1. 5 - Cooking ware jugs from Maloutena site: 1-5 - Cypriot, type III; 6-9 - so-called Aegean. Drawing and digitalization by the author 


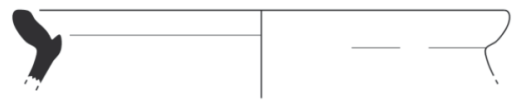

1

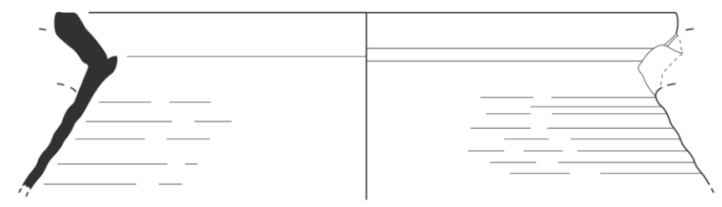

3

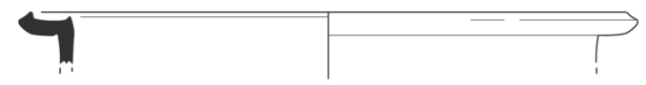

5

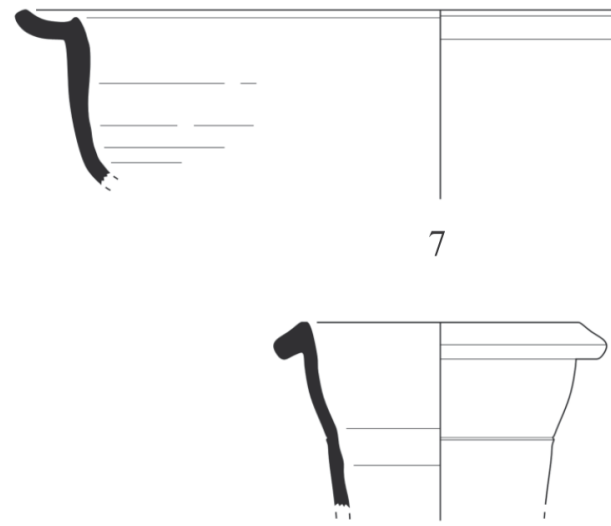

9

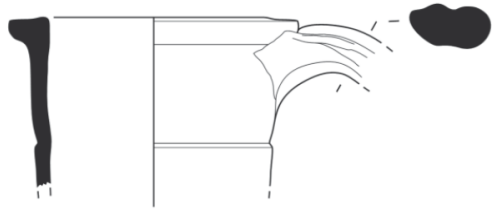

11

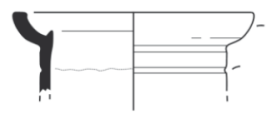

6

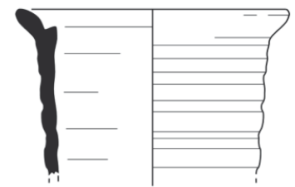

2

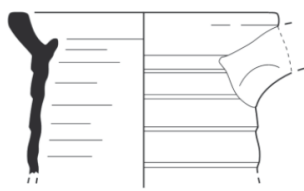

4

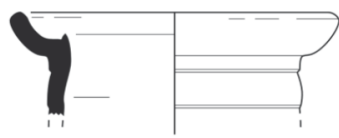

8
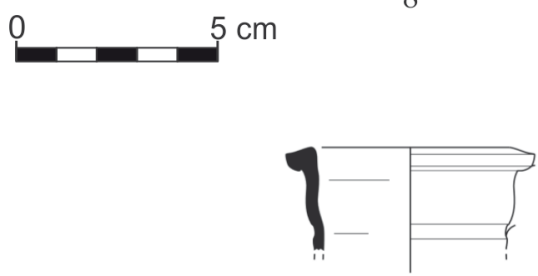

10

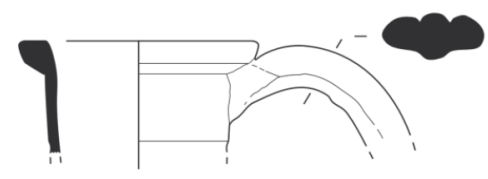

12

Pl. 6 - Cooking ware from Maloutena site: 1, 3 - deep pots; 2, 4, 6, 8 - jugs type II; 5, 7 - casseroles; 10, 12 - jugs type III; table wares: 9 - Red Slip jug, 11 - Plain ware jug. Drawing and digitalization by the author 

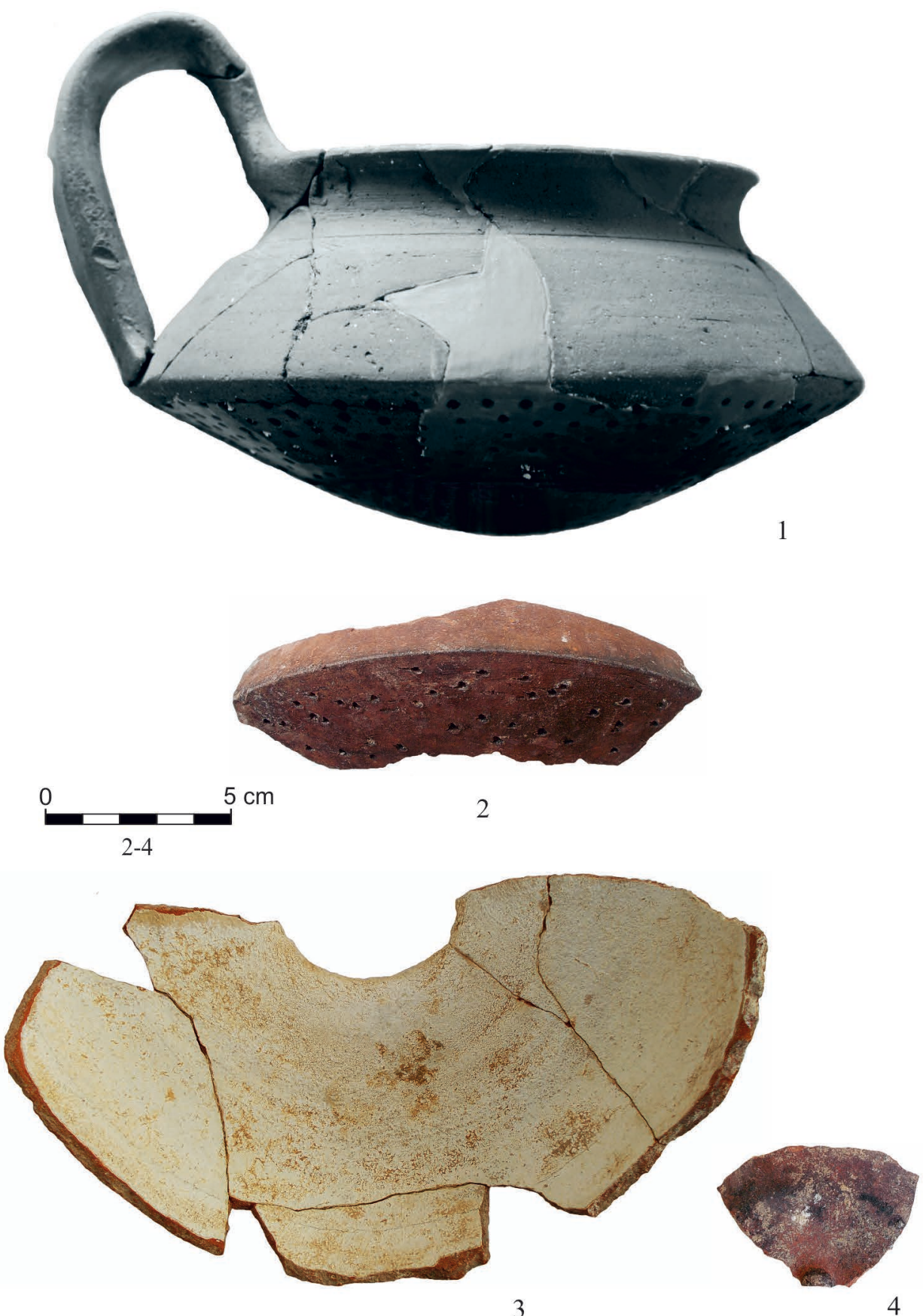

Pl. 7 - Pictures of colanders and jugs: 1 - Colander from the Athenian Agora Museum; 2 - Body sherd of a colander from Maloutena site; 3 - Mineral deposit on the inside of a cooking ware jug from Maloutena site; 4 - Cooking ware jug bottom with traces of soot from Maloutena site. Photo by the author 

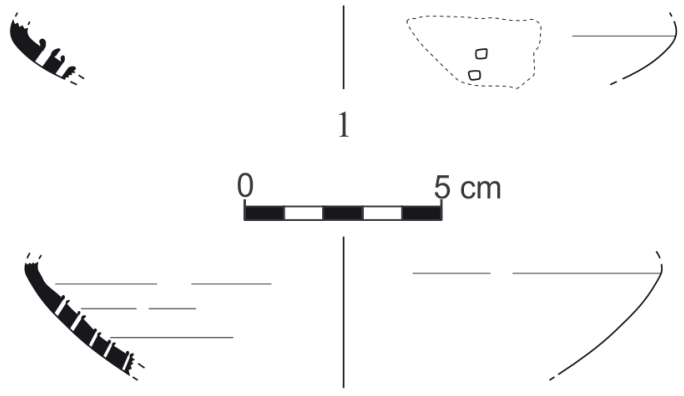

2
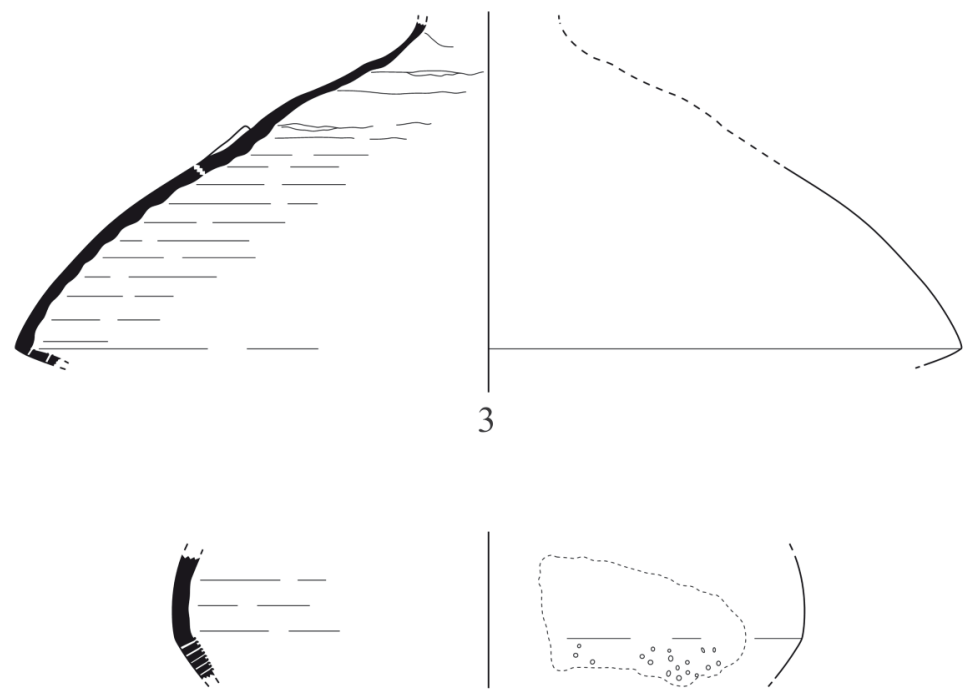

4
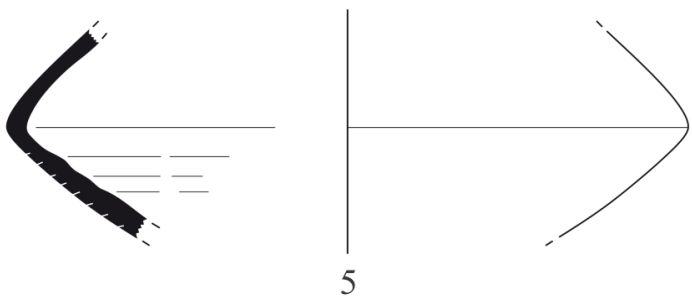

Pl. 8 - Cypriot cooking ware colanders and related from Maloutena site. Drawing and digitalization by the author 